УДК 336.7:338.246.025.2(100)

DOI: https://doi.org/10.32782/2520-2200/2018-5-31

\author{
Семеног А.Ю. \\ кандидат економічних наук, доцент, \\ доцент кафедри фрінансів, \\ банківської справи та страхування \\ Сумського державного університету \\ Цирулик С.B. \\ аспірант \\ Сумського державного університету
}

\title{
ЗАРУБІЖНИЙ ДОСВІД РЕГУЛЮВАННЯ FINTЕСН ПОСЛУГ
}

У статті на основі аналізу наукових джерел розглянуто зарубіжний досвід регулювання FinTech послуг. Охарактеризовано особливості системи регулювання та нагляду в зарубіжних країнах, визначено переваги та недоліки систем регулювання на основі правил та принципів. Здійснено порівняльний аналіз використання регуляторної ппісочниці» у зарубіжних країнах, визначено спільні та відмінні риси, виділено переваги та недоліки використання даного виду регулювання сфрери Fintech послуг. Розроблено структурно-рекомендаційну модель створення вітчизняної регуляторної «пісочниці».

Ключові слова: Fintech послуги, регулювання та нагляд, фінансова установа, ринок фрінансових послуг, фрінансові послуги, регуляторна «пісочниця».

В статье на основе анализа научных источников рассмотрен зарубежный опыт регулирования FinTech услуг. Охарактеризованы особенности системы регулирования и надзора в зарубежных странах, определены преимущества и недостатки систем регулирования на основе правил и принципов. Осуществлен сравнительный анализ использования регуляторной «песочницы» в зарубежных странах, определены общие и отличительные черты, выделены преимущества и недостатки использования данного вида регулирования сфреры Fintech услуг. Разработана структурно-рекомендательная модель создания отечественной регуляторной «песочницы».

Ключевые слова: Fintech услуги, регулирование и надзор, финансовое учреждение, рынок финансовых услуг, фринансовые услуги, регуляторная «песочница».

The article examines scientific sources about the foreign experience of FinTech services. The features of the regulation and supervision system in foreign countries are described. Considering the potential vulnerability of FinTech to fraud and cybercrime services, supervisors use alternative methods of monitoring and risk control, including: the authority to inspect a third-party provider of FinTech services for the bank; regulatory requirements for contracts that provide the permission for supervision; ongoing monitoring of the FinTech services provider activities. Mostly regulators use two approaches for FinTech services regulation: based on rules and on principles. It was established that in their activity supervisory bodies rely on innovative technologies such as: artificial intelligence; distributed registers; unstructured data analysis. To ensure the right balance between ensuring financial stability and protecting consumer rights, regulators are turning to the development of such methodological approaches and innovative solutions as innovative hubs, Fintech accelerators, regulating "sandboxes". Also, the comparative analysis of the use of the regulatory "sandbox" in foreign countries was carried out. The key elements of sandboxes are the purpose of creation, the right to contact the sandbox, the criteria for risks, guarantees and other restrictions, the time for application and testing, the costs for the regulator and participants of the "sandbox", the actions of the regulator after the testing. The common and distinctive features of the "sandboxes" in the countries of the world were characterized. Moreover, the advantages and disadvantages of using this type of the Fintech services regulation were highlighted. The stages of the operating process for potential clients of "sandbox", which include the stages of preliminary classification, application submission, application evaluation, experiment, ending participation in the "sandbox" were presented. A structural and advisory model for the creation of a national regulatory "sandbox" was developed.

Keywords: Fintech services, regulation and supervision, financial institution, financial services market, financial services, regulatory "sandbox".

Постановка проблеми. FinTech стартапи та сервіси - один із найбільш динамічних сегментів сучасної економіки. Деякі з них фрормують нові сегменти у структурі ринку фрінансових послуг та складають конкуренцію вже звичним нам фрінансовим установам, інші доповнюють функ- 
ціонал існуючих банків, страхових компаній, інвестиційних фондів, виступаючи в ролі інноваційно-технологічних доповнень. Нові фрінансові технології вже встигли зацікавити багатьох інвесторів та сорормувати мільйонні бюджети для розвитку та масового впровадження своїх ідей. Новостворені фрінансові продукти намагаються задовольнити існуючі потреби та передбачити майбутні труднощі в розвитку фрінансової сорери. Змінюючи традиційну концепцію фрінансових послуг FinTech компанії сфрормували нову нішу в рамках ринку фрінансових послуг, динамічний розвиток якої зумовлює актуальність розробки та впровадження ефективної системи регулювання та нагляду.

Аналіз останніх досліджень і публікацій. Питання зарубіжного досвіду регулювання FinTech послуг знайшли відображення у працях зарубіжних науковців: Лі Б. (Li B.), Хорслі Дж. (Horsley J.), Валласа А. (Wallace A.), Херболта А. (Herrboldt A.), а також регулятивних та нормативних документах національних регуляторів банківської діяльності та ринків фрінансових послуг. Також активні дослідження ведуться колективами авторів, що представляють Базельский комітет з банківського нагляду (The Basel Committee on Banking Supervision), Організації банківських досліджень (Community Bank Research), Конференції державних банківських наглядачів (Conference of State Bank Supervisors), Європейської банківської асоціації (European Banking Authority), Управління фрінансової поведінки (Financial Conduct Authority).

Метою дослідження $€$ узагальнення зарубіжного досвіду регулювання FinTech послуг та розробка моделі вітчизняного регулювання даної сфери.

Виклад основного матеріалу дослідження. Враховуючи світові тенденції та глобальність економічних процесів, система регулювання вітчизняної сорери FinTech послуг не може розвиватися без залучення досвіду найбільш розвинутих ринків фрінансових послуг, що зумовлює необхідність дослідити світовий досвід регулювання FinTech на основі аналізу відповідних нормативно-правових актів, рекомендацій та ініціатив закордонних регуляторів. Відзначимо, що сфрера FinTech послуг набула найбільшого поширення у таких країнах як Китай, Великобританія та США, що зумовило відповідний розвиток регуляторного та наглядового забезпечення у даних країнах. Так, у Китаї регуляторами у сорері FinTech послуг є: Народний банк Китаю, Китайська комісія з регулювання банківської діяльності, Китайська регуляторна комісія зі страхування, Управління інформаційних інтернет-технологій Китаю [1; 2]. Основним нормативними документами $€$ "The Guiding
Opinions on Promoting the Healthy Development of Internet Finance", "Administrative Measures for Online Payment Business of Non-Bank Payment Institutions". У Великобританії регулювання здійснюють Управління фрінансовою поведінкою [3; 4] та Казначейство Ї̈̈ Величності [5], які керуються такими рекомендаціями як "Project Innovate" та "Regulatory Innovation Plan". Водночас, найбільш розгалужена система нагляду фрункціонує у США, де дана сфрера входить у компетенцію Управління контролера грошового обігу ("The OCC's Responsible Innovation Framework and Fintech Bank Charters-Latest Developments") [6; 7], Федеральної корпорації по страхуванню депозитів (“Marketplace Lending") [8], Комісії з цінних паперів і бірж ("Crowdfunding regulations") [9; 10], Конфреренції державного банківського нагляду (“Vision 2020 for Fintech and Non-Bank Regulation") [11], Бюро з фрінансового захисту споживачів ("Prepaid Accounts Under the Electronic Fund Transfer Act (Regulation E) and the Truth In Lending Act (Regulation Z)") [12], Комісії з торгівлі товарними фр'ючерсами [13] (“LabCFTC").

Аналіз вищенаведених нормативних документів засвідчив, що регулювання більшості ризиків, які пов'язані з розвитком FinTech послуг у даних країнах відносяться до компетенції різних наглядових органів, що вимагає міжсекторального співробітництва між державними інституціями. Як правило нагляд за FinTech сфрерою покладено автономні підрозділи з виділеними ресурсами і лініями звітності для розробки регулятивної бази та дослідження FinTech сфрери. Мандати цих підрозділів мають широкомасштабний характер і включають такі функції, як: політика регулювання FinTech; ліцензування; контакти 3 громадськістю; використання нових технологій нагляду. У своїй діяльності наглядові органи опираються на інноваційні технології, такі як: штучний інтелект (для виявлення аномалій у даних); розподілені регістри (для моніторингу ризиків і угод учасників ринку в режимі реального часу); аналіз неструктурованих даних (для підтримки оцінок ризиків фінансових установ, що надають FinTech послуги).

Зазначимо, що державні регулятори приділяють значну увагу питанню участі FinTech компаній в якості сторонніх постачальників послуг для банків. Зокрема, в нормативних актах та рекомендаціях зазначається, що використання компаній FinTech в якості сторонніх постачальників послуг може допомогти фрінансовим установам у доступі до нових продуктів, технічних експертних знань та ефективності. Водночас, суттєво зростають ризики вразливості банку від шахрайства та кіберзлочинності. Fintech 
рішення, що використовуються багатьма фрінансовими установами можуть представляти системний ризик для фрінансового сектору, тому наглядові органи розробили альтернативні способи моніторингу та контролю ризиків, що включають: повноваження перевіряти стороннього постачальника послуг; нормативну вимогу до договорів, яка передбачає дозвіл на проведення нагляду; постійний процес контролю за діяльністю постачальника послуг.

Також значна увага збоку регуляторних структур приділяється системі ліцензування FinTech послуг, аналіз якої дає змогу виокремити такі її особливості:

- режими ліцензування, як правило, мають ряд варіантів, які включають повні банківські ліцензії, обмежені банківські ліцензії та інші види ліцензій з вимогами та обмеженнями, які варіюються в залежності від типу Fintech організації та/або діяльності;

- повністю нові Fintech продукти та послуги, як правило, підлягають обмеженим видам ліцензування.

Однією з ключових тенденцій, яка була визначена в ході аналізу, стало те, що для забезпечення правильного балансу між забезпеченням фрінансової стабільності та захистом прав споживачів, залишаючи при цьому можливості для Fintech інновацій, регулятори вдаються до розробки методичних підходів та інноваційних рішень, щодо покращення взаємодії з Fintech компаніями, зокрема за рахунок створення:

- інноваційних хабів;

- Fintech акселераторів;

- регуляторних "пісочниць».

Назви вище зазначених ініціатив адаптовані до конкретних регуляторних органів та відрізняються залежно від країни (каталізатор, лабораторія інновацій, інноваційна програма, служба підтримки тощо). Зокрема, програми під однією і тією ж назвою можуть відрізнятися з точки зору ресурсів і мандата. Діапазон дій кожної програми є конкретним і залежить від нормативно-правової бази і мандата регулятора.

Загалом, за підсумками проведеного аналізу нормативно-правових актів рекомендацій та ініціатив, направлених на регулювання FinTech послуг, можемо констатувати, що регулятори використовують два підходи до регулювання FinTech послуг:

- регулювання засноване на правилах;

- регулювання засноване на принципах.

Дані системи регулювання мають як позитивні, так і негативні сторони. Регулювання засноване на правилах дає впевненість і передбачуваність діяльності, забезпечує конкретну поведінку фрінансових установ, водночас стри- мує інновації, на яких по суті й розвивається copepa FinTech послуг, потребує постійного оновлення, вимагає високих витрат на дотримання. Режим регулювання на основі принципів є більш гнучким стосовно динамічності сорери FinTech послуг, дозволяє використовувати світові практики регулювання. Разом з тим, даний вид регулювання може викликати сумніви стосовно неупередженості в застосуванні заходів впливу на фрінансові установи. Даний вид $є$ гнучким, але може створити рівень невизначеності щодо того, що саме очікується від фінансових установ.

Аналіз систем регулювання сфери FinTech послуг засвідчив, що найбільшого поширення набув підхід на основі регулювання з відкритим вихідним кодом, а саме регулятивної «пісочниці» [14; 15]. Так, станом на 01.01.2018 року 9 зарубіжних країн активно використовували регулятивну «пісочницю" (Великобританія, Австралія, Бахрейн, Канада, Гонконг, Малайзія, Нідерланди, Сінгапур, Тайланд), 3 зарубіжні країни почали етап встановлення регулятивної «пісочниці» (Бруней, Індонезія, Сьєрра-Леоне), а 13 зарубіжних країн офріційно анонсували створення регулятивної «пісочниці» (Бразилія, Китай, Індія, Йордан, Японія, Кенія, Мексика, Росія, Південна Корея, Швеція, Швейцарія, Тайвань, Туреччина).

У нашому дослідження для аналізу практик зарубіжних країн, щодо створення регулятивної «пісочниці» були відібрані такі країни як: Сінгапур, Гонконг, Австралія, Великобританія, Канада, Бахрейн, Тайланд, Малайзія.

Вибір саме цих країн обумовлений тим, що перші п'ять із них відносяться до країн із розвиненою Fintech екосистемою та економікою, що у свою чергу вплинуло на створення їхніми регуляторами більш досконалого та детального плану розробки та фрункціонування регулятивних пісочниць. Вибір останніх трьох країн обумовлюється схожістю їх економічного розвитку та розвитку сорери Fintech послуг з вітчизняними показниками.

Перша регулятивна "пісочниця" у світі була запропонована Управлінням фрінансовою поведінкою Великобританії, згідно якого пісочниця - це «безпечний простір», в якому підприємства можуть тестувати інноваційні продукти та послуги, бізнес-моделі і механізми доставки, без негайного виникнення всіх нормативних наслідків для участі у відповідній діяльності» [16]. Наступною була ініціатива Австралії, яка представила своє бачення "пісочниці» як природнього розширення інноваційного хабу Австралійської комісії з цінних паперів та інвестицій. Аналогічні підходи були використані й у інших країнах (табл. 1). 
Таблиця 1

Порівняльний аналіз регуляторних «пісочниць» у зарубіжних країнах

\begin{tabular}{|c|c|c|c|c|c|}
\hline \multirow{2}{*}{ Країна } & \multicolumn{3}{|c|}{$\begin{array}{l}\text { Охоплення } \\
\text { учасників }\end{array}$} & \multirow{2}{*}{$\begin{array}{c}\text { Структура } \\
\text { Тривалість } \\
\text { експерименту }\end{array}$} & \multirow{2}{*}{ Направлення } \\
\hline & B2B & B2C & ФУ & & \\
\hline $\begin{array}{l}\text { Велико- } \\
\text { британія }\end{array}$ & + & + & + & До 6 місяців & $\begin{array}{l}\text { Блок додатків включає широкий спектр } \\
\text { FinTech рішень. }\end{array}$ \\
\hline Австралія & + & - & - & До 12 місяців & $\begin{array}{l}\text { Fintech рішення, які потребують австралій- } \\
\text { ської ліцензії фінансових послуг (AFS) або } \\
\text { кредитної ліцензії, такі як фрінансова кон- } \\
\text { сультація та схвалення кредиту. }\end{array}$ \\
\hline Сінгапур & + & + & + & $\begin{array}{l}6 \text { місяців, дозволя- } \\
\text { ється продовження }\end{array}$ & $\begin{array}{l}\text { Блок додатків включає широкий спектр } \\
\text { FinTech рішень }\end{array}$ \\
\hline Гонконг & - & + & + & $\begin{array}{c}\text { Визначається в } \\
\text { результаті діалогу } \\
\text { з регулятором } \\
\end{array}$ & $\begin{array}{l}\text { Біометрія, DLT, аутентифрікація, послуги з } \\
\text { торгівлі цінними паперами, послуги API, } \\
\text { чатбот і програмні токени. }\end{array}$ \\
\hline Канада & + & + & + & $\begin{array}{c}\text { Визначається в } \\
\text { результаті діалогу } \\
\text { з регулятором }\end{array}$ & $\begin{array}{l}\text { Менеджер інвестиційного фоонду для } \\
\text { криптовалютного інвестиційного фонду, } \\
\text { онлайн-платформи, що сприяють венчур- } \\
\text { ним інвестиціям в стартапи. }\end{array}$ \\
\hline Тайланд & + & + & + & $\begin{array}{l}\text { Менше одного } \\
\text { року }\end{array}$ & $\begin{array}{l}\text { Інвестиційні консультації, управління при- } \\
\text { ватними фрондами, операції з деривативами, } \\
\text { консультації по операціях з деривативами. }\end{array}$ \\
\hline Малайзія & + & + & + & $\begin{array}{l}12 \text { місяців, дозволя- } \\
\text { ється продовження }\end{array}$ & $\begin{array}{l}\text { Перший блок включав такі Fintech рішення, } \\
\text { як фрінансове порівняння, страхове агрегу- } \\
\text { вання, валюто-обмінні операції і надання } \\
\text { грошових переказів }\end{array}$ \\
\hline Бахрейн & + & + & + & $\begin{array}{l}9 \text { місяців, дозволя- } \\
\text { ється продовження } \\
\text { на } 3 \text { місяці }\end{array}$ & $\begin{array}{l}\text { Перший блок додатків включав такі Fintech } \\
\text { рішення, як валюто-обмінні послуги, гро- } \\
\text { шові перекази та мобільний банкінг. }\end{array}$ \\
\hline
\end{tabular}

Джерело: систематизовано авторами на основі [16-24]

Не зважаючи на значне різноманіття регуляторних «пісочниць», всі вони складаються зі схожих конструкційних елементів:

- цілі «пісочниці» (визначаються мандатом регулятора і зазвичай викладаються в установчому документі);

- право звернутися до «пісочниці» (залежить в першу чергу від повноважень регулятора та правової бази);

- критерії щодо ризиків, гарантій та інших обмежень (суб'єкти регулятивної «пісочниці» піддані обмеженням, таким як максимальна кількість клієнтів, додаткові гарантії, які покривають ризики пропонованих інновацій, включаючи розкриття інорормації та створення компенсаційного фонду);

- строки для подачі заявки та проведення тестування (заявники повинні продемонструвати готовність до тестування Fintech інновацій. Тестування має бути обмеженим за часом для запобігання тривалого дослідження інновацій, які або недостатньо розвинуті, або просто не життєздатні);

- витрати для регулятора і учасників «пісочниці» (у більшості країн «пісочниця" надається безкоштовно, водночас існують витрати, пов'язані з проведенням тестування послуги. Наприклад, юридичний супровід, аудит);

- дії регулятора після проведення тестування (успішне тестування Fintech послуги може мати декілька результатів. Перший повноцінний дозвіл на запуск даної інновації для всіх компаній. Другий - індивідуальний дозвіл Fintech компанії на запуск її інновації. Також регулюючі органи можуть ініціювати зміни до правової та нормативної бази, щоб забезпечити юридичну реалізацію Fintech послуги. Якщо тестування виявилося невдалим, фрінансова установа повинна припинити надання Fintech послуги).

Не зважаючи на схожість елементів регулятивних «пісочниць» у більшості аналізованих країн, все ж таки між ними існують певні відмінності та опції (табл. 2).

Аналіз зарубіжного досвіду використання регулятивної «пісочниці» дозволив виділити ряд переваг та недоліків використання даного виду регулювання сорери Fintech послуг [16-24]. Потенційними перевагами є:

- зниження вхідних бар'єрів для небанківських установ;

- сприяння реформам у сфрері регулювання; 
Порівняльний аналіз регулятивних «пісочниць» за елементами та опціями

\begin{tabular}{|c|c|c|}
\hline Елемент & Опції & Країни \\
\hline \multirow{4}{*}{ Ціль (i) } & Інновації & Великобританія, Гонконг \\
\hline & Конкуренція & Бахрейн, Тайланд, Великобританія \\
\hline & Переваги для споживачів & $\begin{array}{l}\text { Бахрейн, Тайланд, Великобританія, } \\
\text { Сінгапур }\end{array}$ \\
\hline & Фінансова інтеграція & Бахрейн, Малайзія, Тайланд \\
\hline \multirow{4}{*}{ Прийнятність } & $\begin{array}{l}\text { Регульовані і перспективні поста- } \\
\text { чальники фрінансових послуг }\end{array}$ & Австралія, Тайланд, Канада, Сінгапур \\
\hline & Всі новатори & Малайзія \\
\hline & $\begin{array}{l}\text { Вся продукція / діяльність (в межах } \\
\text { компетенції регулятора) }\end{array}$ & Тайланд, Канада, Сінгапур, Великобританія \\
\hline & Певні продукти / види діяльності & Австралія, Тайланд \\
\hline \multirow{5}{*}{ Гарантії } & Мінімальний капітал & Великобританія \\
\hline & AML/CFT & $\begin{array}{l}\text { Австралія, Великобританія, Гонконг, } \\
\text { Канада }\end{array}$ \\
\hline & Захист споживачів & $\begin{array}{l}\text { Австралія, Великобританія, Тайланд, } \\
\text { Малайзія, Гонконг }\end{array}$ \\
\hline & $\begin{array}{l}\text { Кількісні ліміти (максимальна кількість } \\
\text { клієнтів, активів під управлінням) }\end{array}$ & Австралія, Бахрейн, Малайзія \\
\hline & Вимоги до звітності & $\begin{array}{l}\text { Австралія, Малайзія, Великобританія, } \\
\text { Тайланд }\end{array}$ \\
\hline \multirow{2}{*}{ Таймінг } & Чітко визначений (Блоковий) & Бахрейн, Великобританія \\
\hline & Плаваючий & Австралія, Малайзія, Канада \\
\hline
\end{tabular}

Джерело: систематизовано авторами на основі [16-24]

- передача інфрормаційного «меседжу» Fintech індустрії та суспільству про підтримку інновацій з боку регулюючих органів;

- підвищення правової визначеності для новаторів;

- зниження витрат новаторів через відсутність необхідності юридичної консультації по тлумаченню регулятивно-правових норм;

- скорочення тривалості процедур авторизації та ліцензування;

- надання регулятивному органу можливості більш глибокого і своєчасного вивчення і розуміння інновацій та їх ризиків, що може підвищити ефективність нагляду.

Натомість потенційними недоліками можуть бути:

- нездатність створити та забезпечити ефективні гарантії для клієнтів і учасників ринку, на яких може негативно вплинути Fintech послуга;

- імовірність штучного скорочення конкуренції;

- відсутність реального усунення перешкод, які не пов'язані з нормативною чи наглядовою структурою;

- нездатність забезпечити відповідні фрінансові ресурси для фрункціонування «пісочниці»;

- отримання непередбачених витрат та юридичної відповідальності у зв'язку з негативним впливом FinTech послуги;

- можливість формування відчуття того, що після успішних експериментів в «пісочниці» інновації позбавленні ризику і гарантовані державою.

Дослідження зарубіжних практик функціонування регулятивних «пісочниць» засвідчують наявність універсальних етапів операційного процесу для потенційних клієнтів «пісочниці»:

1. Стадія попередньої класифрікації - на офріційній веб-сторінці регулятора публікуються основні критерії оцінки, які використовуються для відбору заявок для входу до регулятивної «пісочниці».

2. Стадія подачі заявки - попередня оцінка заявки регулятором на основі отриманої інфрормації. Регулятор повідомляє заявника про потенційну придатність чи не придатність його заявки.

3. Стадія оцінки заявки - відбувається поглиблена оцінка заявки. Заявнику у письмовій формі повідомляється про рішення регулятора, щодо доцільності продовження його співпраці з "пісочницею".

4. Стадія експерименту - надання FinTechпослуги клієнтам під моніторингом регулятора. Fintech фрірма повідомляє своїх клієнтів про те, що FinTech-послуга працює в «пісочниці» $\mathrm{i}$ розкриває основні ризики, пов'язані з даною послугою. У разі, якщо заявник має намір ввести суттєві зміни у фінансово-технологічну послугу в ході експерименту, він повинен повідомити про це регулятора. У разі, якщо заявник просить продовження періоду «пісочниці», він 
звертається до регулятора у визначений термін до закінчення дії «пісочниці».

5. Закінчення участі в «пісочниці» - після закінчення строку дії пісочниці, заявник надає звіт про результати тестування регулятору, на основі якого робиться висновок про масштабування даної Fintech послуги в межах всього ринку, зміни в нормативному забезпеченні чи припинення надання даної послуги.

Беручи до уваги проаналізовані структурні елементи регулятивної «пісочниці» та існуючу універсальну модель ії̈ операційного процесу представимо структурно-рекомендаційну модель створення регулятивної пісочниці, яка сприятиме створенню вітчизняним регулятором ефективної регулятивної «пісочниці» (рис. 1).

На першому етапі «визначення сорери регулювання пісочниці» відбувається: визначення регуляторів залежно від сфери діяльності фрінансової установи, що надає Fintech послугу; оцінка ризику Fintech послуг, що підлягають регулюванню через "пісочницю»; визначення сфрери дії пісочниці на основі автентичності інновацій і того, чи може послуга або продукт регулюватися існуючими нормативними актами. Деструктивні інновації, які ставлять перед регулюючими органами нові завдання, повинні стати частиною «пісочниці», для того щоб створити нормативну інфрраструктуру, яка могла б сприяти розвитку інновацій, при цьому захищаючи інтереси всіх учасників ринку.

Другий етап передбачає наявність плану функціонування регулятивної «пісочниці» та мети її запровадження і складається з наступних кроків:

- визначення учасників: на донному кроці відбувається визначення учасників «пісочниці» у такий спосіб, щоб у ній були представлені учасники різного розміру і масштабу

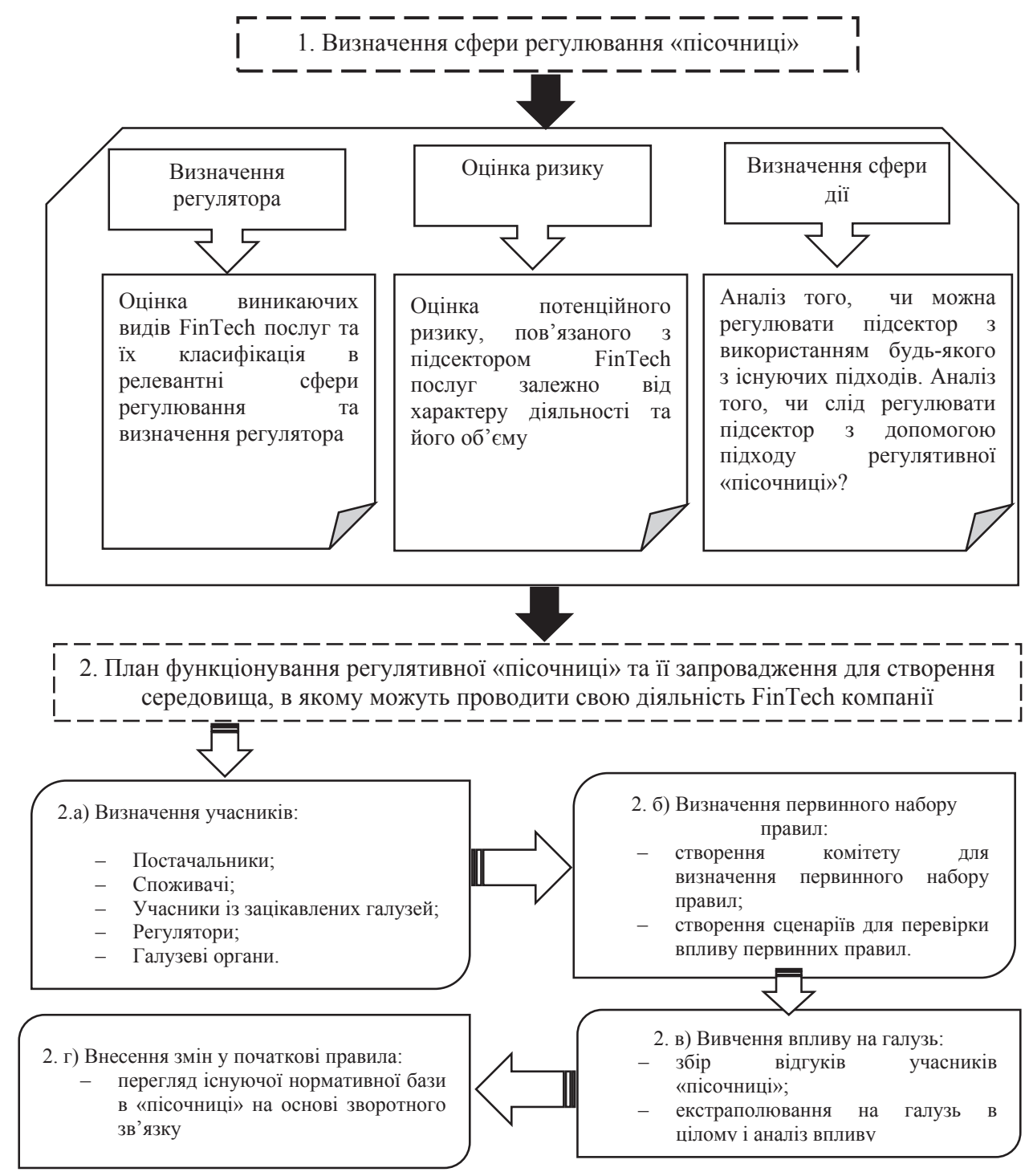

Рис. 1. Структурно-рекомендаційна модель створення регулятивної «пісочниці» 
для забезпечення відсутності монополізму. Слід також налагодити партнерські стосунки 3 видатними інкубаторами для створення стійкої екосистеми;

- визначення початкового набору правил: на даному кроці створюється комітет, який представляє всіх учасників пісочниці для допомоги регулятору у визначенні початкових правил. Слід забезпечити, щоб даний набір правил не збільшував нормативне навантаження на постачальників FinTech-послуг в тій мірі, яка призводить до невигідності ведення бізнесу. При розробці правил необхідно враховувати такі аспекти, як управління, планування безперервність бізнесу, інтерфейс користувача і вимоги до звітності.

- вивчення впливу на галузь: наданому кроці проводиться оцінка впливу Fintech-послуги на споживачів, конкурентів та ринок в цілому.

- внесення поправок у початкові правила: даний крок полягає у внесенні поправок до початкового набору правил, які не чинять значного тиску на постачальників FinTech послуг, зберігають довіру інвесторів і мінімізують діловий ризик.

Таким чином, вищенаведена регулятивна «пісочниця", створена у відповідності до структурно-рекомендаційної моделі, буде сприяти досягненню стійких результатів, які $€$ частиною більш всеосяжного пакету ініціатив щодо стимулювання інновацій та усунення осно- вних недоліків, які блокують корисні інновації на ринку фрінансових послуг. Дані пакети ініціатив можуть включати: удосконалення нормативно-правової бази; періодичний огляд і вдосконалення процесів ліцензування фрінансових послуг та продуктів, заходи, спрямовані на підвищення конкуренції і стимулювання інновацій в країні у цілому; регулярне проведення оцінок регулятивного впливу; фрінансову та юридичну підтримка Fintech прискорювачів та інкубаторів.

Висновки з проведеного дослідження. За підсумками аналізу регулятивного законодавства у зарубіжних країнах стосовно сфери FinTech послуг було виявлено, що регулювання більшості ризиків, які пов'язані з розвитком FinTech послуг відносяться до компетенції різних наглядових органів, що вимагає міжсекторального співробітництва між державними інституціями. У своїй діяльності наглядові органи опираються на інноваційні технології, такі як: штучний інтелект; розподілені регістри; аналіз неструктурованих даних. Переважно регулятори використовують два підходи до регулювання FinTech послуги: на основі правил та на основі принципів. Серед країн аналізу найбільшого поширення набув підхід на основі регулювання з відкритим вихідним кодом, а саме регулятивної «пісочниці», головною метою якої $є$ підтримка інновацій на ринку фрінансових послуг.

\section{Список використаних джерел:}

1. Li B. China issues comprehensive regulations on internet finance. Norton Rose Fulbright. 2015. URL: http://www.nortonrosefulbright.com/knowledge/publications/133500/china-issuescomprehensive-regulations-on-internet-finance.

2. Horsley J. Notice on Issuing the Guiding Opinions on Promoting Development of the Sharing Economy. 2017. URL:http://www.chinalawtranslate.com/wp-content/uploads/2017/08/2017-7-28Sharing-Economy-Opinions-JPH-Tr.pdf.

3. Wallace A. Project Innovate. Financial Conduct Authority. 2016. URL: http://www.meti.go.jp/ committee/kenkyukai/sansei/fintech/pdf/006_02_00.pdf.

4. Official website of FCA Innovate. 2017. URL: $\bar{h} t \mathrm{pss}: / / w w w . f c a . o r g . u k / f i r m s / f c a-i n n o v a t e$.

5. Regulatory Innovation Plan. HM Treasury. 2017. URL: https://www.gov.uk/government/uploads/ system/uploads/attachment_data/file/606953/HM_Treasury_Regulatory_Innovation_Plan.pdf.

6. The OCC's Responsible Innovation Framework and Fiñtech Bank Charters-Latest Developments. The Comptroller of the Currency. 2017. URL: http://www.jonesday.com/files/Publication/0ca79769-65e5-40f8-b7e5-12354198ba73/Presentation/PublicationAttachment/7ab2c44a-3ac5-403f-b1aa-2ac654ad79cb/OCC\%20Responsible\%20Innovation\%20Framework.pdf.

7. Responsible Innovation Home. The Comptroller of the Currency. 2017. URL: https://www.occ.gov/ topics/responsible-innovation/index-innovation.html.

8. Herrboldt A. Marketplace Lending. Federal Deposit Insurance Corporation. 2015. URL: https://www.fdic.gov/regulations/examinations/supervisory/insights/siwin15/si_winter2015article02.pdf.

9. Regulation crowdfunding, general rules and regulations. Electronic Code of Federal Regulations. 2017. URL: https://www.ecfr.gov/cgi-bin/text-idx?SID =34b3261feed0101e23a49dd3ae21f087\&mc =t rue\&tpl=/ecfrbrowse/Title17/17cfr227_main_02.tpl.

10. Regulation Crowdfunding. Securities and Exchange Commission. 2017. URL: https://www.sec.gov/ smallbusiness/exemptofferings/regcrowdfunding.

11. Vision 2020 for Fintech and Non-Bank Regulation. CSBB. 2017. URL: https://www.csbs.org/ vision2020. 
12. Consumer Financial Protection Bureau. Prepaid Accounts Under the Electronic Fund Transfer Act (Regulation E) and the Truth In Lending Act (Regulation Z). Consumer Financial Protection Bureau. 2016. URL: https://www.federalregister.gov/documents/2016/11/22/2016-24503/prepaid-accountsunder-the-electronic-fund-transfer-act-regulation-e-and-the-truth-in-lending-act.

13. LabCFTC. Commodity Futures Trading Commission. URL: http://www.cftc.gov/LabCFTC/index.htm.

14. The Basel Committee on Banking Supervision, consultative document: Sound Practices: Implications of fintech developments for banks and bank supervisors. Bank for International Settlements. 2017. URL: https://www.bis.org/bcbs/publ/d415.pdf.

15. Regulatory Sandboxes. A proposal to EBA by the Banking Stakeholders Group. European Banking Authority. 2017. URL: https://www.eba.europa.eu/documents/10180/807776/BSG+Paper+on+Reg ulatory+Sandboxes_20+July+2017.pdf.

16. Regulatory sandbox. Financial Conduct Authority. 2015. URL: https://www.fca.org.uk/publication/ research/regulatory-sandbox.pdf.

17. ASIC's regulatory sandbox. Australian Securities and Investments Commission. 2017. URL: http://download.asic.gov.au/media/4221445/john-price-speech-perth-fintech-meetup-published21-april-2017.pdf.

18. FinTech Regulatory Sandbox Guidelines. Monetary Authority of Singapore. - 2016 URL: http://www.mas.gov.sg/ /media/MAS/News\%20and\%20Publications/Consultation\%20Papers/ Consultation\%20Paper\%20on\%20FinTech\%20Regulatory\%20Sandbox\%20Guidelines.pdf.

19. SFC Regulatory Sandbox. Securities and Futures Commission. 2017. URL: http://www.sfc.hk/web/ EN/sfc-fintech-contact-point/sfc-regulatory-sandbox.html.

20. CSA Regulatory Sandbox: official web page. Canadian Securities Administrators. 2016. URL: https://www.securities-administrators.ca/industry_resources.aspx?id=1588.

21. Bank of Thailand Public Hearing on Guidance to Participate the Regulatory Sandbox. 2017. URL: http://silklegal.com/bank-of-thailand-public-hearing-on-guidance-to-participate-the-regulatorysandbox/.

22. Financial Technology Regulatory Sandbox Framework. Bank Negara Malaysia. 2016. URL: http://www.bnm.gov.my/index.php? $\mathrm{ch}=57 \& \mathrm{pg}=137 \& a c=533 \& b b=$ file.

23. Financial Technology Regulatory Sandbox Framework. Bank Negara Malaysia. 2016. URL: http://www.bnm.gov.my/index.php?ch=en_announcement \&pg=en_announcement\&ac $=467$.

24. Regulatory Sandbox Consultation Paper. Central Bank of Bahrain. 2017. URL: http://www.cbb.gov.bh/assets/Consultations/Consultation-Regulatory \%20Sandbox-\% 20 28March\%202017.pdf. 